\title{
Combined Herbivory by Targeted Sheep Grazing and Biological Control Insects to Suppress Spotted Knapweed (Centaurea stoebe)
}

\section{Authors: Jeffrey C. Mosley, Rachel A. Frost, Brent L. Roeder, Tracy K. Mosley, and Gerald Marks}

This is a postprint of an article that originally appeared in nvasive Plant Science and Management in January 2016.

Mosley, Jeffrey C. , Rachel A. Frost, Brent L. Roeder, Tracy K. Mosley, and Gerald Marks. "Combined Herbivory by Targeted Sheep Grazing and Biological Control Insects to Suppress Spotted Knapweed (Centaurea stoebe)." Invasive Plant Science and Management 9, no. 1 (January 2016): 22-32. DOI: 10.1614/IPSM-D-15-00034.1. 


\title{
Combined Herbivory by Targeted Sheep Grazing and Biological Control Insects to Suppress Spotted Knapweed (Centaurea stoebe)
}

\author{
Jeffrey C. Mosley, Rachel A. Frost, Brent L. Roeder, Tracy K. Mosley, and Gerald Marks
}

\begin{abstract}
The use of biological control insects is a promising option for suppressing spotted knapweed, a nonindigenous perennial forb that infests more than 3 million hectares of North American rangeland. Efficacy increases when spotted knapweed is attacked by more than one phytophagous insect; however, combined herbivory by biological control insects has not achieved widespread suppression of spotted knapweed in North America. Here we expand the concept of combined herbivory beyond two or more species of biological control insects to include a vertebrate herbivore, specifically targeted grazing by domestic sheep. Our experiment on foothill rangeland in northwestern Montana evaluated spotted knapweed response to three treatments: (1) biological control insects only, (2) biological control insects + targeted sheep grazing applied in late July (spotted knapweed in late bud-early flower stage), and (3) biological control insects + targeted sheep grazing applied in mid-August (spotted knapweed in full-flower stage). We combined targeted sheep grazing with herbivory by three species of biological control insects: knapweed flower weevil, knapweed root weevil, and sulfur knapweed root moth. Treatments were applied during four consecutive years (2009 to 2012). Spotted knapweed fitness was suppressed more where targeted sheep grazing and biological control insects were combined vs. areas treated with biological control insects alone. Combined herbivory was effective when targeted sheep grazing was applied during either late July or mid-August, but July grazing was more effective. Spotted knapweed produced 96 to $99 \%$ fewer viable seeds in sheep-grazed areas. After 4 yr of treatment, total spotted knapweed plant density (seedlings, juvenile, and adult plants) was $86 \%$ less in July-grazed areas and $61 \%$ less in August-grazed areas than in areas treated with biological control insects alone. Combined herbivory by targeted sheep grazing and biological control insects reduced adult plant density and prevented compensatory recruitment of spotted knapweed, but treatment with biological control insects alone did not.
\end{abstract}

Nomenclature: Knapweed flower weevil, Larinus spp.; knapweed root weevil, Cyphocleonus achates; sulfur knapweed root moth, Agopeta zoegana; spotted knapweed, Centaurea stoebe L.

Key words: Biological control, compensatory recruitment, cumulative stress, resource dilution, targeted livestock grazing. 
Spotted knapweed (Centaurea stoebe L.) is a perennial, invasive forb that reduces livestock and wildlife forage (Rice et al. 1997; Watson and Renney 1974), reduces biodiversity (Tyser and Key 1988), increases surface-water runoff and soil erosion (Lacey et al. 1989), and inflicts dramatic economic damage (Bucher 1984; Duncan 2005; Hirsch and Leitch 1996). Spotted knapweed was introduced from Eurasia to British Columbia, Canada, circa 1883

(Müller-Schärer and Schroeder 1993); first collected in the United States in western Montana in 1935 (MüllerSchärer and Schroeder 1993); and currently infests more than 3 million hectares of North American rangeland in 46 U.S. states and seven Canadian provinces (Duncan 2005).

Numerous species of biological control insects have been introduced to suppress spotted knapweed in North America (Wilson and Randall 2005), but sheep grazing is a useful tool for suppressing broadleaf weeds, including spotted knapweed (Olson et al. 1997; Olson

North American spotted knapweed plants tolerate insect herbivory more than spotted knapweed found in its native European habitat (Ridenour et al. 2008). Efficacy of biological control insects increases when spotted knapweed is attacked by more than one phytophagous insect (Knochel et al. 2010b; Müller-Schärer and Schroeder 1993; Seastedt et al. 2007; Story et al. 2008), formally conceptualized as the "cumulative stress hypothesis" (Müller-Schärer 1991; Müller-Schärer and Schroeder 1993). Combined herbivory also negates "overcompensation responses" (Knochel and Seastedt 2010; Knochel et al. 2010b; Seastedt et al. 2007), where herbivory by a single biological control agent sometimes benefits spotted knapweed fitness (Callaway et al. 1999; Newingham et al. 2007). Nevertheless, despite localized successes in Colorado (Knochel and Seastedt 2010; Knochel et al. 2010b; Maines et al. 2013a; Seastedt et al. 2007), British Columbia (Gayton and Miller 2012), and Montana (Story et al. 2006), combined herbivory by biological control insects has not achieved widespread suppression of spotted knapweed in North America and it continues to spread exponentially (Duncan 2005).

One opportunity to increase the efficacy of spotted knapweed control is to expand the concept of combined herbivory beyond two or more species of biological control insects to include vertebrate herbivores, specifically domestic livestock, as suggested by Müller-Schärer and Schroeder (1993) and Story et al. (2006). Previous research and application has demonstrated that targeted and Launchbaugh 2006). Targeted sheep grazing is best applied when spotted knapweed is in either the late bud-early flower phenotypic stage or the full-flower phenotypic stage (Benzel et al. 2009; Henderson et al. 2012; Surber et al. 2011; Thrift et al. 2008). However, it is unknown whether targeted sheep grazing and biological control insects applied together provide greater control of spotted knapweed than biological control insects alone. Our study investigated whether targeted sheep grazing would be better combined with biological control insects when spotted knapweed was in the late bud-early flower phenotypic stage (late July) or the full-flower phenotypic stage(midAugust).Wehypothe-sized that spotted knapweed fitness (i.e., seed production, seedling/juvenile plant density, and adult plant density) would be less where herbivorybytargetedsheepgrazing and biological control insects was combined vs. areas trea-ted with biological control insects alone. We also hypothe-sized that spotted knapweed would respond similarly if treated with targeted sheep grazing in either late July or mid-August.

\section{Materials and Methods}

Study Area. Our field experiment was conducted on foothill rangeland of the Salish Mountains $\left(47^{\circ} 40^{\prime} \mathrm{N}\right.$, $\left.114^{\circ} 16^{\prime} \mathrm{W}\right)$ on tribal lands of the Confederated Salish and Kootenai Tribes in northwestern Montana near Polson, MT. Annual precipitation at our study site averages 385 $\mathrm{mm}$ (15 in), with 60\% received from April through September (WRCC 2014). Elevation is $945 \mathrm{~m}(3,100 \mathrm{ft})$. Our study site was located within the bluebunch wheatgrass [Pseudoroegneria spicata (Pursh) Á. Löve]/Sandberg bluegrass (Poa secunda J. Presl.) habitat type (Mueggler and Stewart 1980). The soil type was classified as BigArm cobbly loam (USDA-NRCS 2014), and the ecological site was Droughty Steep within the Northern Rocky Mountains Major Land Resource Area (USDA-NRCS 2009). Spotted knapweed dominated the plant community, comprising about $50 \%$ of the vegetative composition. Western yarrow (Achillea millefoilium L.) was another common forb; bluebunch wheatgrass and Fendler threeawn [Aristida purpurea Nutt. var. longiseta (Steud.) Vasey] were the dominant perennial grasses; and cheatgrass (Bromus tectorum L.) was the dominant annual grass.

Cyphocleonus achates (Coleoptera: Curculionidae), the knapweed root weevil, and Larinus minutus and Larinus obtusus (Coleoptera: Curculionidae), the knapweed flower weevils, were prevalent on the study site. Previous research has documented that combined herbivory by Cyphocleonus and Larinus can suppress spotted knapweed (Knochel et al. 2010b; Seastedt et al. 2007; Story et al. 2006). Agapeta 
zoegana (Lepidoptera: Cochcylidae), the sulfur knapweed root moth, is another biological control insect for spotted knapweed that also was prevalent on our study site. Urophora spp. (Diptera: Tephritidae), a seed-head-eating fly that has been released for biological control of spotted knapweed, was present but rare and not quantified in our experiment. The life histories of Cyphocleonus, Larinus, and Agapeta have been summarized elsewhere (Story 2004a,b; Story and Coombs 2004a,b; Wilson and Randall 2005). In brief, Cyphocleonus adult weevils emerge midsummer and live mostly just below the soil surface, except on warm, sunny days when they climb to the tops of spotted knapweed plants in search of a mate. Adults oviposit in the taproot or root crown of spotted knapweed, and larvae feed on the central vascular tissue of the taproot during fall, winter, and spring. Agapeta adult moths begin emerging 3 to 4 wk earlier than Cyphocleonus, live aboveground for 10 to $14 \mathrm{~d}$, and oviposit on the leaves and stems of spotted knapweed plants. Larvae hatch and move immediately into the root cortex of spotted knapweed, where they feed during fall, winter, and spring. Larinus adults become active in late spring to early summer. They oviposit during seed formation in spotted knapweed flower heads, where larvae hatch and feed on spotted knapweed seeds (achenes) in the seedheads (capitulae). At spotted knapweed senescence, Larinus adults emerge and move into plant litter and soil near spotted knapweed stem bases where Larinus adults overwinter.

Treatments. Twelve 0.26 -ha $(0.64-\mathrm{ac})$ paddocks were constructed. Four paddocks were grazed by sheep in 2009, 2010, 2011, and 2012 when spotted knapweed was in the late bud-early flower stage (late July treatment), and four paddocks were grazed by sheep in 2009, 2010, 2011, and 2012 when spotted knapweed was in the full-flower stage (mid-August treatment). Therefore, each year we applied targeted sheep grazing before spotted knapweed had produced viable seeds. Four paddocks were not grazed by sheep, representing the effects of biological control insects alone.

Field densities of the biological control insects were not manipulated and insects were not confined within each paddock, following the methods of Jacobs et al. (2006), Knochel and Seastedt (2010), and Maines et al. (2013b). Accordingly, herbivory by the biological control insects was a full-site scale treatment rather than a per-paddock treatment (Jacobs et al. 2006). We did not include sheeponly treatments because insecticide applications or cages to eliminate the biological control insects from the sheepgrazed paddocks also would have eliminated pollinator insects and prevented seed production by spotted knapweed, an obligate outcrosser (i.e., a plant that requires pollinator insects to transfer pollen from another individual plant to produce seed; Harrod and Tyler 1995). Spotted knapweed seed production and seedling recruitment are important metrics of spotted knapweed's ability to persist in a plant community because spotted knapweed reproduces solely by seed. Investigations of potential ways to suppress spotted knapweed should quantify seed production and seedling recruitment.

Ten yearling Rambouillet ewes grazed within each of the four paddocks in the late-July and mid-August treatments one time per year (total $=40$ ewes $\mathrm{mo}^{-1} \mathrm{yr}^{-1}$ ). We equated sheep grazing pressure among the grazed paddocks by keeping sheep in the paddocks until a targeted level of use was achieved. Sheep remained grazing in the paddocks until desirable grasses reached an 8- to $10-\mathrm{cm}$ (3- to 4-in) residual stubble height or when $\geq 90 \%$ of spotted knapweed buds, flowers, and seed-heads were removed, whichever occurred first. On average, sheep remained in each grazed paddock for $7 \mathrm{~d}$ per year. Immediately before and after sheep grazing we counted spotted knapweed buds, flowers, and seed-heads within $1050-\times 50-\mathrm{cm}$ quadrats spaced at 3-m intervals along a $30-\mathrm{m}$ transect located near the center of each paddock.

Our targeted grazing prescription was intended to remove as many spotted knapweed buds, flowers, and seed-heads as possible while limiting adverse impacts to perennial graminoids. Grazing to the $8-$ to $10-\mathrm{cm}$ residual stubble height was intended to average about 50 to $55 \%$ utilization (Taylor and Lacey 1999) and thereby remain within sustainable grazing use levels ( 40 to $60 \%$ ) recommended for preferred forage plants on foothill rangelands of western Montana (Lee-Campbell 1999). In both sheep-grazed treatments, targeted grazing was applied when spotted knapweed remained green but desirable grasses and forbs were largely dormant. In a previous research study in western Montana we documented that sheep grazed at this time of year preferentially selected spotted knapweed and avoided graminoids (Henderson et al. 2012). Also, foliar herbivory during mid- to late summer stresses spotted knapweed physiologically at a time when moisture is depleted and lacking for plant recovery (Wooley et al. 2011).

Sheep grazing treatments also were timed to be compatible with the life cycles of Larinus, Agapeta, and Cyphocleonus. For Larinus, targeted sheep grazing in either late July (spotted knapweed in late bud-early flower stage) or midAugust (spotted knapweed in full-flower stage) occurred before most spotted knapweed seed-heads began to develop. Thus, few Larinus larvae eggs or larvae were expected to be consumed by the sheep because Larinus oviposit in the developing seed-heads of spotted knapweed (Story and Coombs 2004a,b). Incidental ingestion of Larinus adults by sheep was possible but unlikely because Larinus adults fly away when disturbed (Knochel and Seastedt 2010). For Agapeta, ingestion of adults by sheep was unlikely because sheep primarily ingest spotted knapweed flower heads during July or August grazing periods (Henderson et al. 2012; 
Olson and Wallander 2001), yet Agapeta adults do not inhabit spotted knapweed flower heads (Wilson and Randall 2005). Agapeta larvae reside in spotted knapweed roots where larvae are largely protected from sheep herbivory and trampling. Similarly, Cyphocleonus larvae and adults live mostly on or inside spotted knapweed roots where they are largely protected from sheep herbivory and trampling. Incidental ingestion of Cyphocleonus adults could possibly occur when they are aboveground searching for mates, but Cyphocleonus adults sit perfectly still atop plants to avoid detection and immediately drop to the ground and play dead when disturbed (Wilson and Randall 2005).

Yearling ewes averaged $68 \mathrm{~kg} \mathrm{animal}^{-1}\left(150 \mathrm{lb}_{\text {animal }}{ }^{-1}\right)$, and stocking rate was about 1.3 animal unit mo ha ${ }^{-1}$. Each month and year, all ewes were randomly assigned to the treatment paddocks following 5-d acclimation grazing periods in an adjacent 2.2-ha paddock. Acclimation grazing periods enabled the sheep to become familiar with the forage on the study site before entering treatment paddocks.

Data Collection and Laboratory Analyses. To affirm that biological control insect numbers were similar in sheepgrazed areas vs. areas treated with biological control insects alone, biological control insect abundance was sampled in all 12 paddocks during mid-July (i.e., prior to sheep grazing) of each treatment year (2009, 2010, 2011, and 2012). Cyphocleonus and Agapeta abundance was sampled within three $1.0-\times 1.0-\mathrm{m}$ quadrats per paddock, spaced at $10-\mathrm{m}$ intervals along a $30-\mathrm{m}$ permanently marked transect located near the center of each paddock. All adult spotted knapweed plants rooted in each $1.0-\times 1.0-\mathrm{m}$ quadrat were excavated, taproots were dissected, and the absence or combined presence of larvae or feeding tunnels was recorded separately for Cyphocleonus and Agapeta (Jacobs et al. 2006; Knochel and Seastedt 2010; Lejeune et al. 2005). Only current year's feeding tunnels were recorded. Current year's feeding tunnels appeared smooth and brown vs. the rough, grey, decayed appearance of previous years' tunnels. Larinus was sampled with sweep nets within three $1.0-\times 3.0-\mathrm{m}$ quadrats per paddock, spaced at $10-\mathrm{m}$ intervals along a permanently marked $30-\mathrm{m}$ transect located near the center of each paddock. Quadrats for insect sampling were spaced so that no single area was sampled twice during the $4 \mathrm{yr}$ of insect sampling. Each quadrat was swept with 15 net passes per sample. Sweep net sampling occurred during warm, dry weather between 1:00 P.M. and 6:00 PM when Larinus were most active, as recommended by Wilson and Randall (2005). Per Seastedt et al. (2007), we did not distinguish Larinus minutus from Larinus obtusus because some authorities consider them to be variants of the same species (Story and Coombs 2004a,b).

At plant senescence, but before seeds dehisced in late August 2009, 2010, 2011, and 2012, all buds, flowers, and seed-heads on spotted knapweed plants were counted and collected within $1050-\times 50-\mathrm{cm}$ quadrats per paddock. These quadrats were spaced at 3-m intervals along a permanently marked 30-m transect located near the center of each paddock, and quadrats for seed sampling were spaced so that no single area was sampled twice during the $4 \mathrm{yr}$ of seed collection. In the laboratory, seeds were extracted from buds, flowers, and seed-heads using a rub board, counted, and tested for viability using the tetrazolium test as described by Benzel et al. (2009) and Frost and Mosley (2012).

Spotted knapweed plant density was sampled in midJuly 2010 to 2013, the year after grazing treatments were applied (i.e., grazing treatments applied in late July and mid-August 2009 to 2012). Density of spotted knapweed seedlings/juvenile plants, however, was recorded during mid-July of only 3 yr, from 2011 to 2013. Spotted knapweed plant density was categorized by age class (seedlings/juveniles vs. adult plants). Seedlings were nonreproductive plants originating in the current growing season, juveniles were nonreproductive plants originating in a prior season, and adults were reproductive plants originating in a prior season (Ortega et al. 2012). Spotted knapweed seedlings were counted within $1050-\times 50-\mathrm{cm}$ quadrats per paddock, spaced at $3-\mathrm{m}$ intervals along a permanently marked 30-m transect near the center of each paddock. Juvenile and adult plants were counted within three $1.0-\times 1.0-\mathrm{m}$ quadrats per paddock, spaced at 10 $\mathrm{m}$ intervals along each transect.

Statistical Analyses. The 0.26-ha paddocks were the experimental units to which the three treatments were randomly assigned, with four paddocks (i.e., replicates) per treatment. Experimental design was a split-plot in time, with three treatments (biological control insects alone, biological control insects + targeted sheep grazing in late July, biological control insects + targeted sheep grazing in mid-August) applied in $4 \mathrm{yr}$ (2009, 2010, 2011, and 2012). The whole-plot factor was treatment, and the subplot factor was year. Data were analyzed with repeated measures analysis of variance in the Mixed Model of SAS software (Version 9.3, SAS Institute, Cary, NC). We examined the main effects of treatment and year and their interaction on spotted knapweed fitness.

Density data were evaluated for deviations from normality using the Shapiro-Wilk test $(\mathrm{P} \leq 0.05)$, and density data were transformed as recommended by Steel and Torrie (1980). Cyphocleonus densities; Agapeta densities; spotted knapweed bud, flower, and seed-head densities; and viable spotted knapweed seed densities were transformed by the square root of $Y+1 / 2$; densities of all spotted knapweed seeds, densities of spotted knapweed seedlings/juvenile plants, and densities of adult spotted knapweed plants 
A.

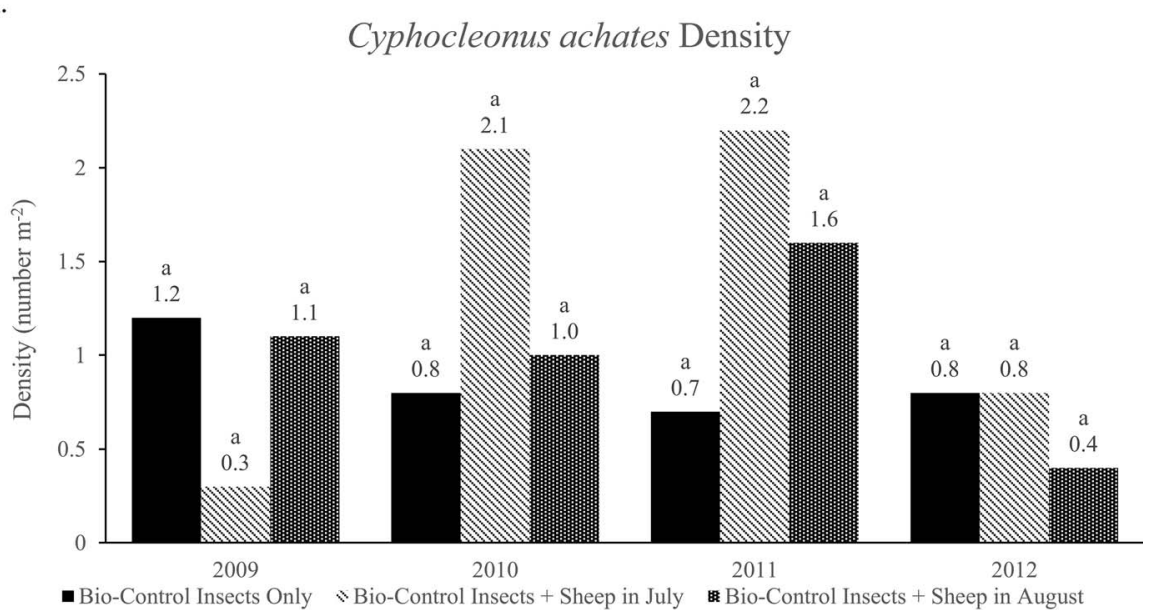

B.

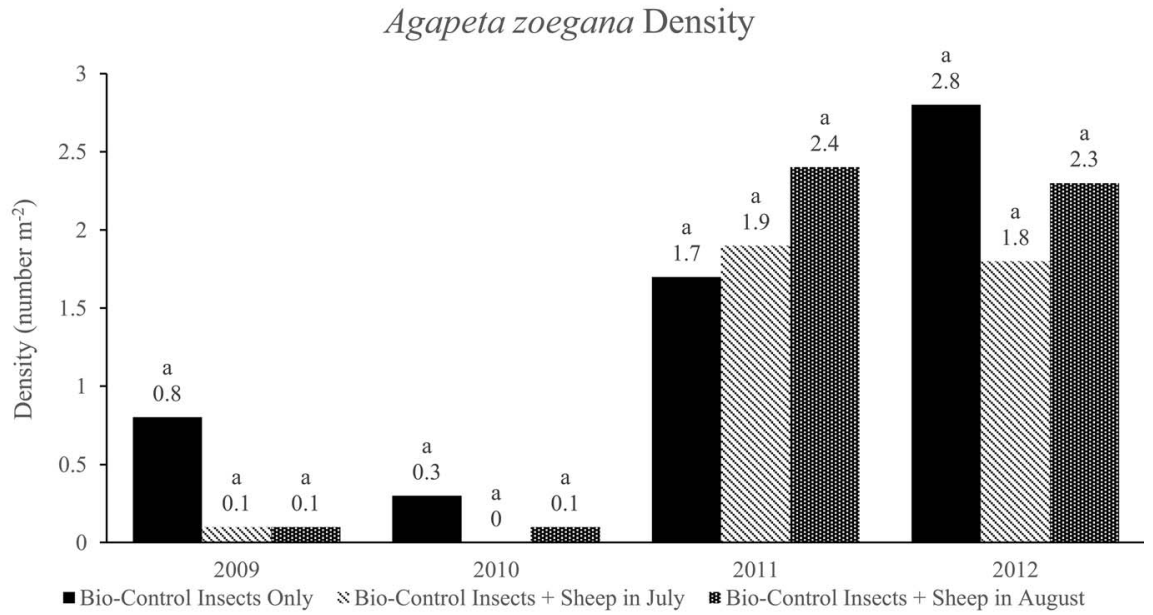

C.

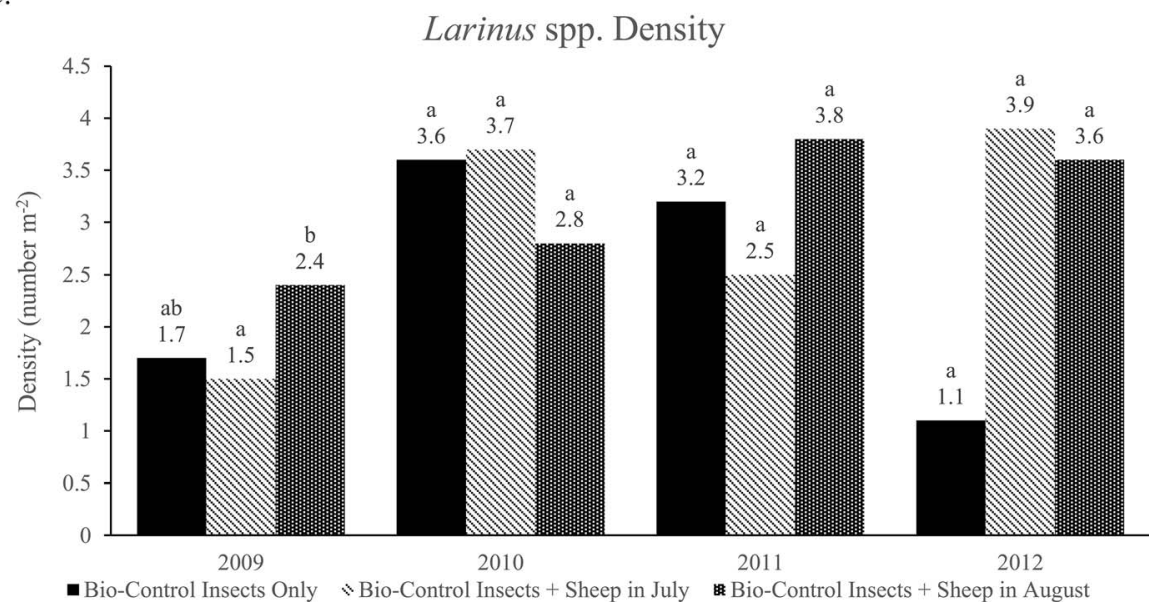

Figure 1. Density of (A) Cyphocleonus, (B) Agapeta, and (C) Larinus in mid-July 2009 to 2012 before treatment with targeted sheep grazing during late July or mid-August 2009 to $2012(n=4$ replicates per treatment). Means within years with the same lowercase letter are not different $(\mathrm{P}>0.05)$.

were transformed by $\log _{10}(\mathrm{Y}+1)$. Means and standard errors presented in the text and figures are from untransformed data. Treatment means were compared using
Tukey's Studentized range test to limit experiment-wise type I errors (Steel and Torrie 1980), and all differences were considered significant at $\mathrm{P} \leq 0.05$. 


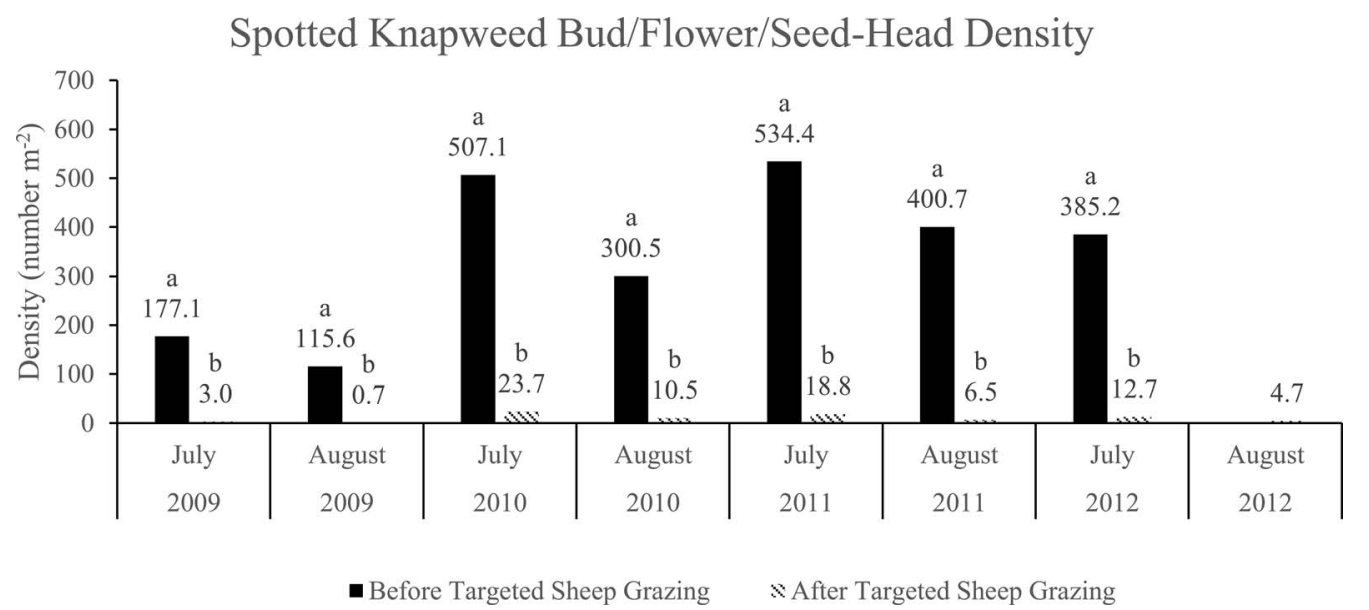

Figure 2. Spotted knapweed bud, flower, and seed-head density immediately before and after targeted sheep grazing during late July or mid-August 2009 to 2012 ( $n=4$ replicates per treatment). Before-grazing data missing from August 2012. Means within the same month-year combination with the same lowercase letter are not different $(\mathrm{P}>0.05)$.

\section{Results and Discussion}

During the $4 \mathrm{yr}$ that targeted sheep grazing was applied, biological control insect densities in sheep-grazed areas never differed $(\mathrm{P}>0.05)$ from areas treated with biological control insects alone (Figure 1). Therefore, levels of herbivory by biological control insects were presumed similar between sheep-grazed areas and areas treated with biological control insects alone. Cyphocleonus density in our study averaged 1.1 larvae $\mathrm{m}^{-2}$ (Figure 1A), which was 2.8 times greater than at two sites in western Montana where Cyphocleonus suppressed spotted knapweed (Story et al. 2006). Densities of Agapeta larvae and Larinus adult moths in our study averaged $1.2 \mathrm{~m}^{-2}$ and $2.8 \mathrm{~m}^{-2}$, respectively (Figures $1 \mathrm{~B}$ and 1C). To the best of our knowledge, per-unit of land area densities of Agapeta larvae and Larinus adults have not been published previously.

Spotted Knapweed Seed Production. Targeted sheep grazing removed 96 and $98 \%$ of spotted knapweed buds, flowers, and seed-heads in July and August, respectively $(\mathrm{P}<0.01$ and $\mathrm{P}<0.01$, respectively; Figure 2$)$, and spotted knapweed produced 93 to $98 \%$ fewer total seeds and 96 to $99 \%$ fewer viable seeds in sheep-grazed areas than in areas treated with biological control insects alone (Figures $3 \mathrm{~A}$ and 3B). Knochel et al. (2010a) and Story et al. (2008) estimated the minimum threshold of seed production needed for a spotted knapweed population to persist, with estimates varying widely, including values of 2,710, 160, and 38 seeds $\mathrm{m}^{-2}$ year ${ }^{-1}$. In our study, total seed production by spotted knapweed in the sheep-grazed areas averaged only 11 seeds $\mathrm{m}^{-2}$ year ${ }^{-1}$ in the August-grazed areas and 36 seeds $\mathrm{m}^{-2}$ year $^{-1}$ in the July-grazed areas (Figure 3A), below the threshold needed for a spotted knapweed population to sustain itself. In contrast, total seed production by spotted knapweed averaged 500 seeds $\mathrm{m}^{-2}$ year $^{-1}$ in the areas treated with biological control insects alone (Figure 3A).

Our results and results from Rinella et al. (2001) and Benzel et al. (2009) indicate that a single defoliation per year during the flowering or seed-producing stage is sufficient to suppress spotted knapweed seed production. Defoliation during the flowering or seed-producing stage is sufficiently late in the growing season that few, if any, viable seeds will be produced if spotted knapweed reflowers after defoliation (Benzel et al. 2009). Decreased viable seed production by spotted knapweed also was reported by Olson et al. (1997) in their study of targeted sheep grazing, where the amount of viable spotted knapweed seed recovered from seedbank cores was $76 \%$ less in sheep-grazed areas. In a clipping study that removed all spotted knapweed buds and flowers during the late bud-early flower phenotypic stage or during the full-flower phenotypic stage, viable seed production of spotted knapweed was reduced 99 to $100 \%$ (Benzel et al. 2009).

Spotted Knapweed Plant Density. After 4 yr of treatment, total spotted knapweed plant density (seedlings, juvenile, and adult plants) was $86 \%$ less in July-grazed areas and $61 \%$ less in August-grazed areas than in areas treated with biological control insects alone $(\mathrm{P}<0.01$; Figure $3 \mathrm{C})$. These among-treatment differences in total spotted knapweed plant density resulted largely from reduced numbers of seedling/juvenile spotted knapweed plants in sheepgrazed areas rather than differences in adult spotted knapweed plant densities (Figures 3D and 3E). Spotted knapweed seedling/juvenile plant density after 4 yr of treatment was $93 \%$ less in July-grazed areas and $68 \%$ less in August-grazed areas compared with biological control insects alone $(\mathrm{P}<0.01$; Figure 3D). Spotted knapweed adult plant density declined $61 \%$ from 2010 to 2013 in 
A.

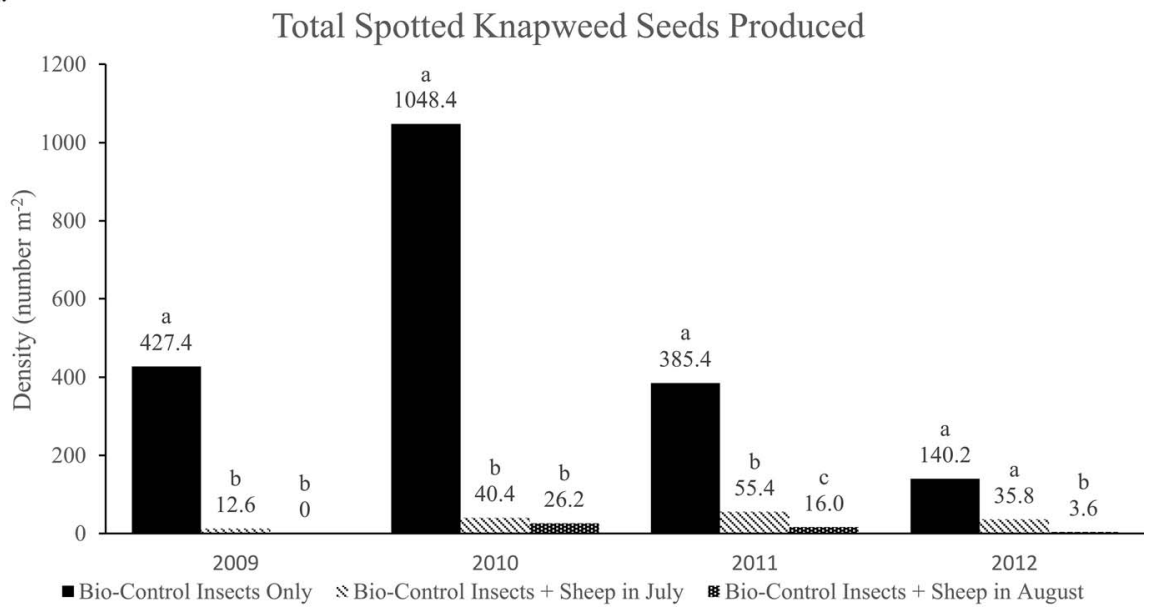

B.

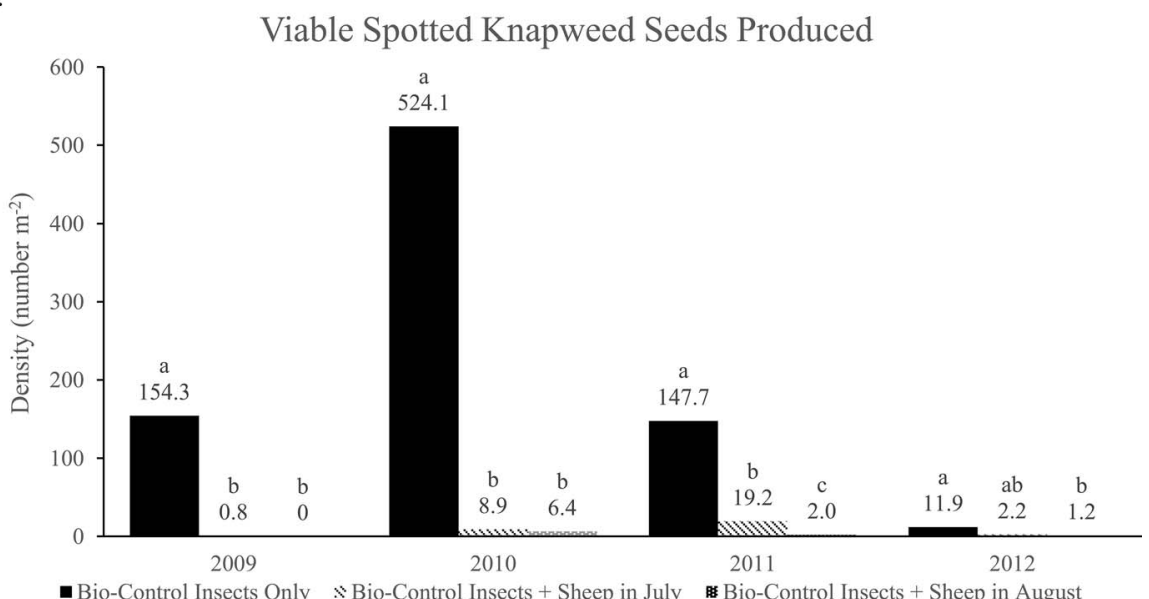

C.

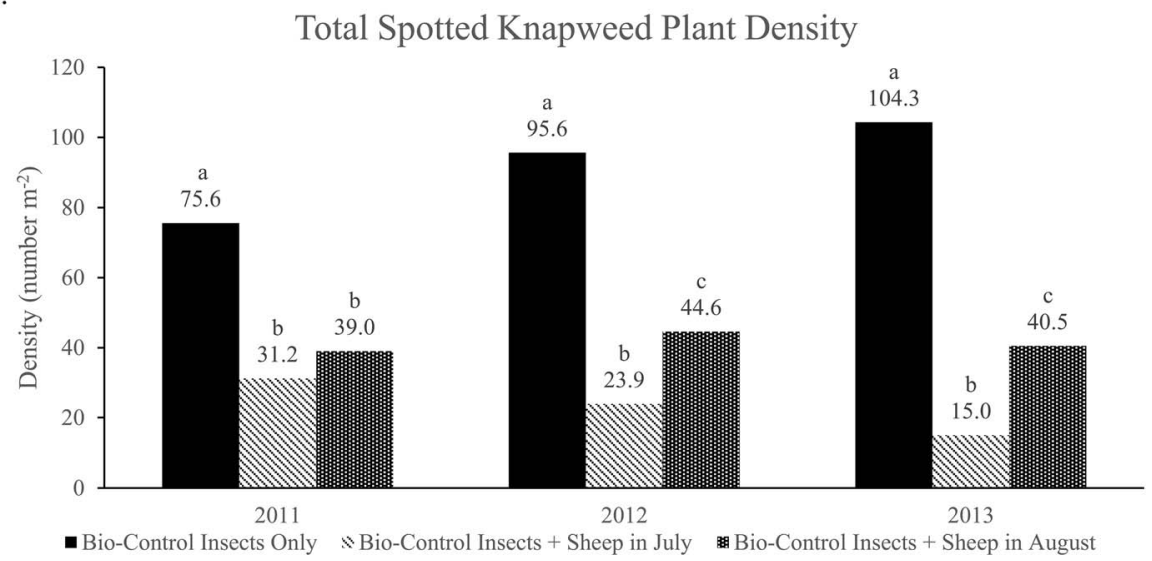

Figure 3. Spotted knapweed fitness after treatment with biological control insects only or biological control insects combined with targeted sheep grazing during late July or mid-August 2009 to 2012 ( $n=4$ replicates per treatment). (A) Total and (B) viable seed production sampled in late August 2009 to 2012. (C) Total spotted knapweed plant density (seedlings, juvenile, and adult plants) and (D) seedling/juvenile plant density sampled in mid-July 2011 to 2013 . (E) Adult plant density sampled in mid-July 2010 to 2013. Means within years with the same lowercase letter are not different $(\mathrm{P}>0.05)$. Means within treatments with the same uppercase letter are not different $(\mathrm{P}>0.05)$. 
D.

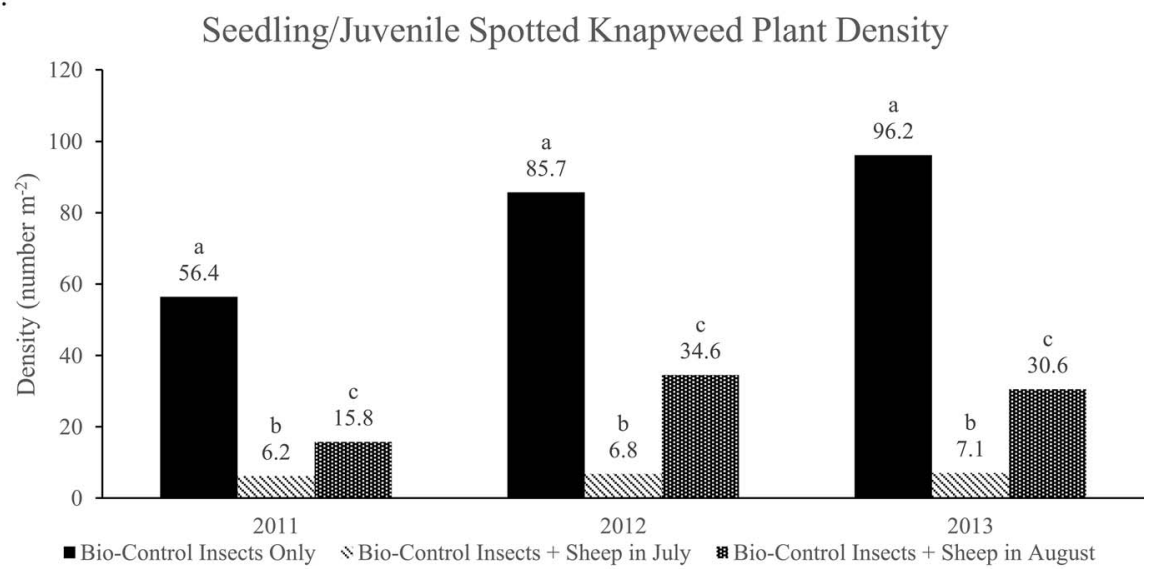

E.

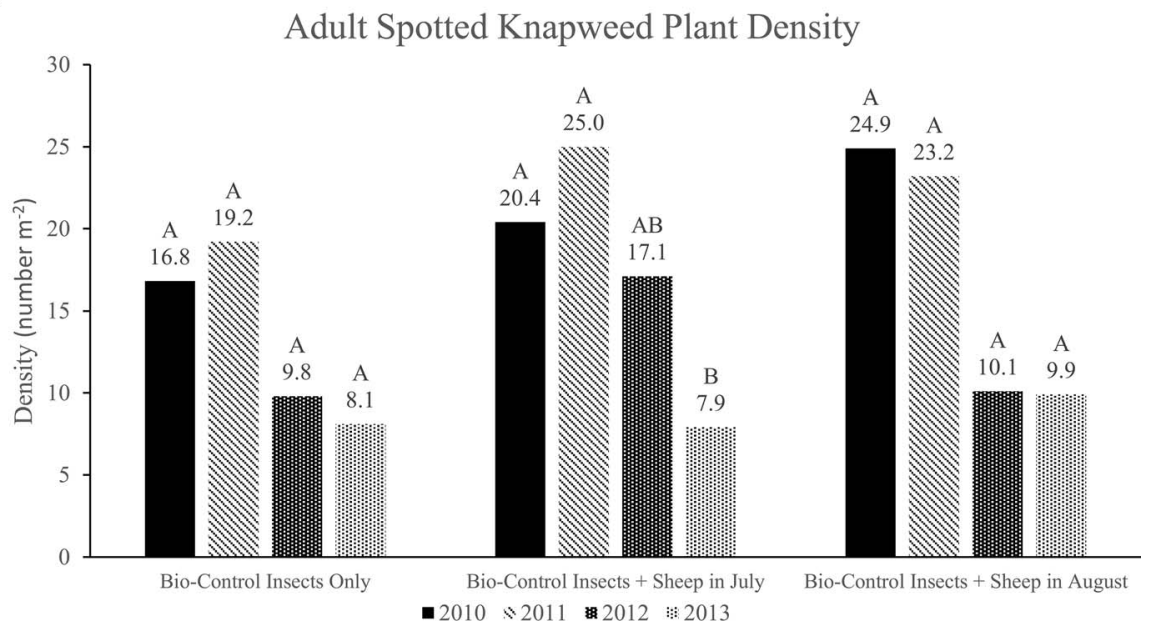

Figure 3. Continued.

July-grazed areas $(\mathrm{P}=0.01)$ while trending $60 \%$ less in August-grazed areas $(\mathrm{P}=0.08)$ and $52 \%$ less in areas treated with biological control insects alone $(\mathrm{P}=0.18$; Figure $3 \mathrm{E})$.

Spotted knapweed seedling/juvenile plant density in the sheep-grazed areas declined, in part, because fewer viable seeds were produced (Figure 3B). Another likely contributing factor was that sheep readily consume juvenile spotted knapweed plants (Olson et al. 1997), whereas Cyphocelonus, Larinus, and Agapeta primarily attack adult spotted knapweed plants (Collins and Müller-Schärer 2012; Maines et al. 2013b; Smith and Story 2003). Herbivory of juvenile spotted knapweed plants by sheep is noteworthy because spotted knapweed populations often compensate in response to control treatments by increasing the rates of spotted knapweed seedling establishment or juvenile plant survival when intraspecific competition is reduced, thereby enabling spotted knapweed populations to tolerate seed loss or plant mortality (Maines et al. 2013a, b; Ortega et al. 2012). However, four years of combined herbivory by targeted sheep grazing and biological control insects in our study reduced adult plant density and prevented compensatory recruitment of spotted knapweed, but treatment with biological control insects alone did not.

An unexpected result was that seedling/juvenile spotted knapweed plants were more abundant in August-grazed areas than July-grazed areas (Figure 3D). We suspect this difference was caused by a greater number of safe-sites in the August-grazed areas. Safe-sites are microsites in soil surface microtopography that provide suitable moisture and temperature for seedlings to establish (Eriksson and Ehrlen 1992; Nathan and Muller-Landau 2000), and abundant safe-sites better enable spotted knapweed populations to persist (Knochel et al. 2010a; Story et al. 2008). Previous research has documented that sheep trampling can create safe-sites and enhance seedling establishment of perennial forbs (Eichberg et al. 2005; Wessels-de Wit and Schwabe 2010), and safe-sites are more often created by trampling when soils are dry (Vallentine 2001:163). We attribute the 
greater densities of seedling/juvenile spotted knapweed plants in the August-grazed vs. July-grazed areas to more safe-sites created by trampling later in summer when soils were drier.

Drought has been implicated as the causal agent in some areas where spotted knapweed abundance has declined (Ortega and Pearson 2011; Pearson and Callaway 2006; Pearson and Fletcher 2008). Drought, however, did not occur at our study site during our 5-yr experiment. A crop year beginning September 1 and ending June 30 is most appropriate for assessing precipitation effects on rangeland plant response in the Intermountain region (Sneva and Britton 1983; Sneva and Hyder 1962). During our study, precipitation received in the September 1 to June 30 crop years of 2008 to 2009,2009 to 2010,2010 to 2011,2011 to 2012 , and 2012 to 2013 was 79,120 , 139,140 , and $100 \%$, respectively, of the prior $30-\mathrm{yr}$ mean (WRCC 2014). Overall, precipitation during the five crop years of our study averaged $108 \%$ of the prior 30-yr mean.

Biological control insect density per target plant is often strongly and negatively related to target plant density, formally referred to as "resource dilution" (Jacobs et al. 2006; Otway et al. 2005; Story et al. 1996). Biological control insect densities per target plant often increase when target plant density decreases, resulting in greater efficacy by the biological control insects (Jacobs et al. 2006; Otway et al. 2005; Story et al. 1996). As mentioned earlier, targeted sheep grazing in our study removed 96 and $98 \%$ of spotted knapweed buds, flowers, and seed-heads in July and August, respectively $(\mathrm{P}<0.01$ and $\mathrm{P}<0.01$, respectively; Figure 2), which probably increased Larinus larval density and feeding damage in the remaining seed-heads. Few Larinus larvae were likely consumed by the sheep because Larinus oviposit in the developing seed-heads of spotted knapweed and we applied targeted sheep grazing during the late bud-early flowering phenotypic stage or the full-flower phenotypic stage, before spotted knapweed seed-heads began to develop.

Demographics of the spotted knapweed population in our experiment were altered where targeted sheep grazing was combined with biological control insects. After four successive years of treatment, adult plants comprised $53 \%$ of the spotted knapweed population in July-grazed areas and $24 \%$ of the spotted knapweed population in August-grazed areas, whereas adult plants comprised only $8 \%$ of the spotted knapweed population in areas ungrazed by sheep (Figures 3C and 3E). Olson et al. (1997) documented similar changes in the age class distribution of spotted knapweed plants after three summers of targeted sheep grazing. Larger proportions of adult vs. seedling/ juvenile plants are worth noting because exponential decreases in plant population size eventually occur whenever too few seedling/juvenile plants exist to replace adult plants that die.
Spotted knapweed populations should decrease exponentially wherever weed management can (1) significantly reduce adult plant density and (2) keep spotted knapweed recruitment below the threshold needed to replace adult plants that die. Sheep-grazed areas in our study met both of these criteria, but areas treated with biological control insects alone did not. Given that most spotted knapweed plants $(>70 \%)$ in untreated populations are 2 or $3 \mathrm{yr}$ old and fewer than 5\% are more than 6 yr old (Olson et al. 1997), spotted knapweed populations should decrease exponentially wherever both criteria can be met for six consecutive years.

Combined herbivory by more than one species of biological control insect may be sufficient to suppress spotted knapweed populations in places where few spotted knapweed seedlings establish and transition to adults (Maines et al. 2013a,b). However, our results and those of Maines et al. (2013a,b) suggest that mammalian herbivory may need to be combined with biological control insects to suppress spotted knapweed in those North American habitats where spotted knapweed seedlings and juvenile plants thrive.

\section{Acknowledgments}

Research was funded by U.S. Department of Agriculture (USDA) Western Integrated Pest Management Center, USDA Western Sustainable Agriculture Research and Education, Montana Noxious Weed Trust Fund, Missoula County Weed District, Montana Agricultural Experiment Station, and Montana State University Extension. We gratefully acknowledge the Polson Indian Stockmen's Association and the Confederated Salish and Kootenai Tribes, especially Doug Dupuis, for providing access to the study site; Ryan Allen, Austin Cantwell, Lindsey Cope, Jason Frost, Charles Glenn, Kelsy Payne, Ben Roeder, Cindy Selensky, and Ben Worthington for assistance with data collection; and Lucy Cooke for assistance with seed viability testing. We also thank Jim Story for his support and guidance.

\section{Literature Cited}

Benzel KT, Brewer TK, Mosley JC (2009) Defoliation timing effects on spotted knapweed seed production and viability. Rangeland Ecol Manag 62:550-556

Bucher RF (1984) The potential cost of spotted knapweed to Montana range users. Bozeman, MT: Montana State University Cooperative Extension Service Bulletin 1316. 18 p

Callaway RM, DeLuca TH, Belliveau WM (1999) Biological-control herbivores may increase competitive ability of the noxious weed Centaurea maculosa. Ecology 80:1196-1201

Collins AR, Müller-Schärer H (2012) Influence of plant phenostage and ploidy level on oviposition and feeding of two specialist herbivores of spotted knapweed, Centaurea stoebe. Biol Control 60:148-153

Duncan CA (2005) Spotted knapweed, Centaurea stoebe L. ssp. Micranthos (Gugler) Hayek. Pages 51-68 in Duncan CA, Clark JK, eds. Invasive Plants of Range and Wildlands and their Environmental, Economic, and Societal Impacts. Lawrence, KS: Weed Science Society of America 
Eichberg C, Storm C, Schwabe A (2005) Epizoochorous and postdispersal processes in a rare plant species: Jurinea cyanoides (L.) Rchb. (Asteraceae). Flora 200:477-489

Eriksson O, Ehrlen J (1992) Seed and microsite limitation of recruitment in plant populations. Oecologia 91:360-364

Frost RA, Mosley JC (2012) Sulfur cinquefoil (Potentilla recta) response to defoliation on foothill rangeland. Invasive Plant Sci Manag 5:408-416

Gayton D, Miller V (2012) Impact of biological control on two knapweed species in British Columbia. J Ecosyst Manag 13:1-14

Harrod RJ, Taylor RJ (1995) Reproduction and pollination biology of Centaurea and Acroptilon species, with emphasis on C. diffusa. Northwest Sci 69:97-105

Henderson SL, Mosley TK, Mosley JC, Kott RW (2012) Spotted knapweed utilization by sequential cattle and sheep grazing. Rangeland Ecol Manag 65:286-291

Hirsch SA, Leitch JA (1996) The impact of knapweed on Montana's economy. Fargo, ND: North Dakota State University Agricultural Experiment Station, Agricultural Economics Report 355. 43 p

Jacobs J, Sing, SE, Martin JM (2006) Influence of herbivory and competition on invasive weed fitness: observed effects of Cyphocleonus achates (Coleoptera:Curculionidae) and grass-seeding treatments on spotted knapweed performance. Environ Entomol 35:1590-1596

Knochel DG, Flagg C, Seastedt TR (2010a) Effects of plant competition, seed predation, and nutrient limitation on seedling survivorship of spotted knapweed (Centaurea stoebe). Biol Invasions 12:3771-3784

Knochel DG, Monson ND, Seastedt TR (2010b) Additive effects of aboveground and belowground herbivores on the dominance of spotted knapweed (Centaurea stoebe). Oecologia 164:701-712

Knochel DG, Seastedt TR (2010) Reconciling contradictory findings of herbivore impacts on the growth and reproduction of spotted knapweed (Centaurea stoebe). Ecol Appl 20:1903-1927

Lacey JR, Marlow CB, Lane JR (1989) Influence of spotted knapweed (Centaurea maculosa) on surface water runoff and sediment yield. Weed Technol 3:627-631

Lee-Campbell K, ed (1999) Best management practices for grazing Montana. Helena, MT: Montana Department of Natural Resources and Conservation. $29 \mathrm{p}$

Lejeune KD, Suding KN, Sturgis S, Scott A, Seastedt TR (2005) Biological control insect use of fertilized and unfertilized diffuse knapweed in a Colorado grassland. Environ Entomol 34:225-234

Maines A, Knochel D, Seastedt T (2013a) Biological control and precipitation effects on spotted knapweed (Centaurea stoebe): empirical and modeling results. Ecosphere 4:1-14

Maines AP, Knochel DG, Seastedt TR (2013b) Factors affecting spotted knapweed (Centaurea stoebe) seedling survival rates. Invasive Plant Sci Manag 6:568-576

Mueggler WF, Stewart WL (1980) Grassland and shrubland habitat types of western Montana. Ogden, UT: U.S. Department of Agriculture, Forest Service, Intermountain Forest and Range Experiment Station, General Technical Report INT-66. $154 \mathrm{p}$

Müller-Schärer H (1991) The impact of root herbivory as a function of plant density and competition: survival, growth, and fecundity of Centaurea maculosa in field plots. J Appl Ecol 28:759-776

Müller-Schärer H, Schroeder D (1993) The biological control of Centaurea spp. in North America: do insects solve the problem? Pestic Sci 37:343-353

Nathan R, Muller-Landau HC (2000) Spatial patterns of seed dispersal, their determinants and consequences for recruitment. Trends Ecol Evol 15:278-285

Newingham BA, Callaway RM, BassiriRad H (2007) Allocating nitrogen away from an herbivore: a novel compensatory response to root herbivory. Oecologia 153:913-920

Olson B, Launchbaugh K (2006) Managing herbaceous broadleaf weeds with targeted grazing. Pages 58-67 in Launchbaugh K, Walker J,
Daines R, eds. Targeted Grazing: A Natural Approach to Vegetation Management and Landscape Enhancement. Centennial, CO: American Sheep Industry Association

Olson BE, Wallander RT (2001) Sheep grazing spotted knapweed and Idaho fescue. J Range Manag 54:25-30

Olson BE, Wallander RT, Lacey JR (1997) Effects of sheep grazing on a spotted knapweed-infested Idaho fescue community. J Range Manag 50:386-390

Ortega YK, Pearson DE (2011) Long-term effects of weed control with picloram along a gradient of spotted knapweed invasion. Rangeland Ecol Manag 64:67-77

Ortega YK, Pearson DE, Waller LP, Sturdevant NJ, Maron JL (2012) Population-level compensation impedes biological control of an invasive forb and indirect release of a native grass. Ecology 93:783-792

Otway SJ, Hector A, Hector JH (2005) Resource dilution effects on specialist herbivores in a grassland biodiversity experiment. J Anim Ecol 74:234-240

Pearson DE, Callaway RM (2006) Biological control agents elevate hantavirus by subsidizing mice. Ecol Lett 9:442-449

Pearson DE, Fletcher RJ Jr (2008) Mitigating exotic impacts: restoring deer mouse populations elevated by an exotic food subsidy. Ecol Appl 18:1489-1500

Rice PM, Toney JC, Bedunah DJ, Carlson CE (1997) Elk winter forage enhancement by herbicide control of spotted knapweed. Wildl Soc B. 25:627-633

Ridenour WM, Vivanco JM, Feng Y, Horiuchi J, Callaway RM (2008) No evidence for trade-offs: Centaurea plants from America are better competitors and defenders. Ecol Monogr 78:369-386

Rinella MJ, Jacobs JS, Sheley RL, Borkowski JJ (2001) Spotted knapweed response to season and frequency of mowing. J Range Manag 54:52-56

Seastedt TR, Knochel DG, Garmoe M, Shoskoy SA (2007) Interactions and effects of multiple biological control insects on diffuse and spotted knapweed in the Front Range of Colorado. Biol Control 42:345-354

Smith L, Story JM (2003) Plant size preference of Agapeta zoegana L. (Lepidoptera:Tortricidae), a root-feeding biological control agent of spotted knapweed. Biol Control 26:270-278

Sneva F, Britton CM (1983) Adjusting and forecasting herbage yields in the Intermountain big sagebrush region of the steppe province. Corvallis, OR: Oregon State University Agricultural Experiment Station Bulletin 659. $61 \mathrm{p}$

Sneva FA, Hyder DN (1962) Estimating herbage production on semiarid ranges in the Intermountain region. J Range Manag 15:88-93

Steel RGD, Torrie JH (1980) Principles and Procedures of Statistics: A Biometrical Approach. 2nd ed. New York: McGraw-Hill. 633 p

Story JM (2004a) Agapeta zoegana. Pages 207-209 in Coombs EM, Clark JK, Piper GL, Cofrancesco AF Jr, eds. Biological Control of Invasive Plants in the United States. Corvallis, OR: Oregon State University Press

Story JM (2004b) Cyphocleonus achates. Pages 212-213 in Coombs EM, Clark JK, Piper GL, Cofrancesco AF Jr, eds. Biological Control of Invasive Plants in the United States. Corvallis, OR: Oregon State University Press

Story JM, Callan NW, Corn JG, White LJ (2006) Decline of spotted knapweed density at two sites in western Montana with large populations of the introduced root weevil, Cyphocleonus achates (Fahraeus). Biol Control 38:227-232

Story JM, Coombs EM (2004a) Larinus minutus. Pages 214-216 in Coombs EM, Clark JK, Piper GL, Cofrancesco AF Jr, eds. Biological Control of Invasive Plants in the United States. Corvallis, OR: Oregon State University Press

Story JM, Coombs EM (2004b) Larinus obtusus. Pages 216-217 in Coombs EM, Clark JK, Piper GL, Cofrancesco AF Jr, eds. Biological Control of Invasive Plants in the United States. Corvallis, OR: Oregon State University Press 
Story JM, Smith L, Corn JG, White LJ (2008) Influence of seed-head attacking biological control agents on spotted knapweed reproductive potential in western Montana over a 30-year period. Environ Entomol 37:510-519

Story JM, White LJ, Good WR (1996) Propagation of Cyphocleonus achates (Fahraeus) (Coleoptera:Curculionidae) for biological control of spotted knapweed: procedures and cost. Biol Control 7:167-171

Surber LMM, Rude ME, Roeder BL, Mosley TK, Grove AV, Walker JW, Kott RW (2011) Percent spotted knapweed (Centaurea stoebe) in the diets of grazing sheep. Invasive Plant Sci Manag 4:95-101

Taylor JE, Lacey J (1999) Monitoring Montana rangeland. Bozeman, MT: Montana State University Extension Service Bulletin 369. 22 p

Thrift BD, Mosley JC, Brewer TK, Roeder BL, Olson BE, Kott RW (2008) Prescribed sheep grazing to suppress spotted knapweed on foothill rangeland. Rangeland Ecol Manag 61:18-25

Tyser RW, Key CH (1988) Spotted knapweed in natural area fescue grasslands: an ecological assessment. Northwest Sci 62:151-159

[USDA-NRCS] U.S.Department of Agriculture-Natural Resources Conservation Service (2009) Droughty Steep Ecological Site Description, Northern Rocky Mountains. Bozeman, MT, USA: Montana Technical Guide, Section II. $26 \mathrm{p}$

[USDA-NRCS] U.S. Department of Agriculture-Natural Resources Conservation Service (2014) Web Soil Survey: Lake County Area,
Montana, BigArm Cobbly Loam. http:/websoilsurvey.nrcs.usda.gov/. Accessed January 7, 2014

Vallentine JF (2001) Grazing Management. 2nd ed. San Diego, CA: Academic Press. 659 p

Watson AK, Renney AJ (1974) The biology of Canadian weeds. 6. Centaurea diffusa and C. maculosa. Can J Plant Sci 54:687-701

Wessels-de Wit S, Schwabe A (2010) The fate of sheep-dispersed seeds: plant species emergence and spatial patterns. Flora 205:656-665

Wilson LM, Randall CB (2005) Biology and biological control of knapweed. 3rd ed. Morgantown, WV: U.S. Department of Agriculture-Forest Service, Forest Health Technology Enterprise Team, FHTET-2001-07. $99 \mathrm{p}$

Wooley SC, Smith B, King C, Seastedt TR, Knochel DG (2011) The lesser of two weevils: physiological responses of spotted knapweed (Centaurea stoebe) to above- and belowground herbivory by Larinus minutus and Cyphocleonus acates. Biocontrol Sci Technol 21:153-170

[WRCC] Western Regional Climate Center (2014) Period of record monthly climate summary, Polson Kerr Dam, Montana. http:// www.wrcc.dri.edu.Accessed January 7, 2014

Received July 25, 2015, and approved December 16, 2015.

Associate Editor for this paper: Darren J. Kriticos, CSIRO Ecosystem Sciences. 